\title{
PENINGKATAN KESEJAHTERAAN MASYARAKAT MELALUI \\ PROGRAM KEMITRAAN PERHUTANI DI KECAMATAN NGANCAR KABUPATEN KEDIRI ( Studi Implementasi Peraturan Menteri Lingkungan Hidup dan Kehutanan No.P.83/MenLHK/Setjen/Kum.1/10/2016 Tentang Kemitraan Kehutanan)
}

\section{Oleh :}

\author{
Teguh Pramono ${ }^{1}$, Rizki Yudha Bramantyo ${ }^{2}$, Gentur Cahyo Setiono ${ }^{3}$, Suwadji $^{4}$
}

\begin{abstract}
Abstraksi
Penduduk terus tumbuh dan berkembang yang dibarengi dengan tumbuhnya berbagai sarana dan fasilitas, baik itu sebagai media tempat tinggal maupun fasilitas bekerja serta berbagai sarana prasarana. Hal tersebut berdampat pada terus berkurangnya lahan pertanian dan kawasan hutan. Akibat selanjutnya adalah seringnya terjadi konflik antara masyarakat sekitar hutan dengan pihak perhutanan, khususnya kawasan hutan lindung dan hutan produksi. Oleh karena itu pemerintah mengeluarkan program kemitraan kehutanaan dengan masyarakat sekitar hutan. Permasalahannya adalah bagaimana meningkatkan kesejahteraan masyarakat sekitar hutan di Kecamatan Ngancar Kabupaten Kediri serta apa yang menjadi kendalanya. Adapun Pendekatan yang digunakan adalah pendekatan kualitatif, dengan teknik penentuan informan dengan teknik purposive serta teknik pengumpulan data menggunakan teknik observasi, dokumentasi dan wawancara. Data yang terkumpul dilakukan validasi data dengan teknik triangulasi. Setelah data diuji dengan validasi data maka dilakukan teknik analisis dengan teknik analisis interaktif.

Menjawab permasalahan pertama dan fokus dari permasalahan pertama tersebut maka dilakukan kerjasama dengan Perhutani dalam bentuk PHBM dan LMDH "Lancar Jaya". Akibat dari kerjasama tersebut petani memiliki lahan pertanian, pembagian lahan dilakukan secara random, tanaman pertanian meliputi nanas,cabai, jagung, dan kacang panjang (tanaman sayuran). Pemasaran dibantu oleh LMDH "Lancar Jaya", dalam pengelolaaan lahan tidak diperbolehkan menggunakan insektisida. Dengan demikian terjadi peningkatan penghasilan dan atau kesejahteraan masyarakat sekitar hutan. Kemudian dapat meminimalisir kerusakan lingkungan dan konflik sosial. Kendala yang dirasakan dalam melaksanakan program kemitraan dan pemberdayaan masyarakat sekitar hutan, antara lain Kendala internal meliputi kurangnya motivasi, dan saratnya pembatsan dalam pengelolaan lahan. Akibatnya hasil panen kurang optimal, mengingat tidak diperbolehkannya penggunaan insektisida serta tiadanya penyuluhan pertanian. Kendala Eksternal antara lain pengaruh iklim/cuaca dan wabah penyakit tanaman. Kata Kunci : Peningkatan Kesejahteraan, kemitraan
\end{abstract}

\footnotetext{
Dosen Fakultas IImu Sosial dan Ilmu Politik Universitas Kadiri

Dosen Fakultas Hukum Universitas Kadiri, email : rizki bramantyo@unik-kediri.ac.id

Dosen Fakultas Hukum Universitas Kadiri, email : gentur@unik-kediri.ac.id

Dosen Fakultas Hukum Universitas Kadiri, email : suwadji@unik-kediri.ac.id
} 


\section{Latar Belakang}

Pertumbuhan penduduk Indonesia sangat pesat (1,49\%/tahun) itu sama dengan rata-rata setiap keluarga memiliki 2 sampai 3 anak dan jika dijumlah menjadi 4,5 juta jiwa/tahun. Jumlah penduduk demikian sama dengan jumlah penduduk Singapura. Jika demikian dapat diprediksi bahwa 20 tahun lagi bayi yang baru lahir tersebut menjadi penduduk usia produktif dan itu artinya pemerintah harus menyediakan banyak lapangan kerja. Kondisi ini akan tambah menjadi parah dan sangat membahayakan jika penduduk yang lahir menjadi penduduk yang tidak berkualitas atau berasal dari keluarga yang tidak berkualitas. Penduduk yang tidak berkualitas adalah penduduk yang tidak mampu berkompetisi atau menyediakan atau mempersiapkan anggota keluarga untuk menghadapi kehidupan di masa yang akan datang. Penduduk yang demikian akan menjad beban masyarakat, pemerintah dan lingkungan. Belum lagi daya dukung lahan untuk menopang kehidupan mereka yang semakin hari semakin menyusut, lahan sawah dan ladang semakin menyusut berubah menjadi lahan perumahan.

Kawasan hutan yang berdekatan dengan permukiman penduduk dimanfaatkan oleh pemerintah untuk areal hutan produksi ataupun hutan lindung Sistem pengawasan hutan demikian oleh Dinas Kehutanan bekerja sama dengan masyarakat sekitar hutan dengan cara masyarakat sekitar hutan tersebut diperkenankan untuk menanami kawasan hutan dengan tanaman pertaniaan, khususnya di kawasan lereng gunung Kelud Kecamatan Ngancar kabupaten Kediri. Permasalahannya adalah bagaimana meningkatkan kesejahteran 
masyarakat sekitar hutan sebagai dampak program kemitraan dan kendala apa yang terjadi dalam pelaksanaan hal tersebut.

Dewasa ini fenomena hutan bulanlah sesuatu yang mengerikan namun menjadi objek wisata, objek ilmu pengetahuan dan inspirasi serta sumber ekonomi, sebagaimana UUK no 41 pasal 1tahun 1999. Menyadari bahwa masyarakat sekitar hutan menggantungkan hidupnya dari hutan dan agar tidak merusak hutan serta ikut menjaga kelestarian hutan maka masyarakat tersebut diberi kesempatan untuk menggarap lahan hutan yang pohonnya baru ditebang, dan semampang menunggu tanaman baru tumbuh besar maka masyarakat sekitar hutan bisa bertani di lahan tersebut, hal demikian disebut dengan petani pesanggem. Para petani pesanggem tersebut menanami lahan perhutani dengan tanaman padi gogo, jagung, kacang tanah, dan atau ketela pohon, dan sementtara lahan yang menjadi pembatas atau pinggiran ditanami dengan pohon lamtoro. Ini dapat diartikan bahwa hutan merupakan daya dukung bagi kehidupan masyarakat sekitar hutan.

\section{Kajian Pustaka}

Menurut Eko Edi Prastyo dan Kliwon Hidayat (2016) dalam Jurnal Habitat Volume 27 menjelaskan bahwa pengelolaan Perum Perhutani masa lalu cenderung timber oriented, yang mana kurang memperhitungkan variabel sosial ekonomi dan budaya. Ini kemudian memunculkan disparsitas atau ketidakseimbangan dalam pemanfaatan sumber daya hutan dan meningkatnya konflik pengelolaan dengan masyarakat sekitar hutan. Hingga lahirlah paradigma baru pengelolaan sumberdaya hutan yang berbasis pada pemberdayaan 
masyarakat melalui kesadaran berbagi hasil, berbagi peran dan berbagi tanggung jawab.

Noer tanggal 22 Juni 2018 menyatakan terdapat tiga pola pemanfaatan hutan pada Kesatuan Pengelolaan Hutan (KPH) yaitu (1) kemitraan kehutana; (2) kerjasama untuk mendukung ketahanan pangan; dan (3) kerjasama pemanfaatan hutan di KPH (https://www.kangnur.com/tiga-pola-kerjasama-pemanfaatanhutan-pada-kesatuan-pengelolaan-hutan/). Payung hukum tentang kemitraan kehutanan tersebut diatur oleh Peraturan Menteri Lingkungan Hidup dan Kehutanan No. P.83/MenLHK/Setjen/Kum.1/10/2016. Kemitraan kehutanan tersebut lahir karena hutan sebagai salah satu bentuk perhutanan sosial. Sesuai dengan namanya yaitu perhutanan sosial, artinya fungsi sosial dari hutan, berarti keberadaan hutan tidak lepas dari manfaat dan interaksi antara masyarakat dan hutan itu sendiri yang hendak dimaksimalkan.

Perhutanan Sosial yang dilakukan antara masyarakat setempat dengan pengelola hutan, pemegang izin pemanfaatan hutan/jasa hutan, izin pinjam pakai kawasan hutan, atau pemegang izin usaha industri primer hasil hutan. (KangNur.com. 22/06/2018).Peraturan pemerintah yang mengatur tentang program kemitraan kehutanan adalah Peraturan Menteri Kehutanan Republik Indonesia Nomor : P.39/Menhut-II/2013 tentang Pemberdayaan Masyarakat setempat melalui Kemitraan Kehutanan. Program Kemitraan kehutanan merupakan program pemberdayaan masyarakat oleh kehutanan, oleh karena itu hukumnya wajib bagi KPH. 
KPH adalah Kesatuan Pengelolaan Hutan yaitu wilayah pengelolaan hutan sesuai fungsi pokok dan peruntukannya, yang dapat dikelola secara efisien dan lestari. Adapun ketentuan areal kemitraan kehutanan, meliputi

1. areal konflik dan yang berpotensi konflik;

2. areal yang memiliki potensi dan menjadi sumber penghidupan masyarakat setempat;

3. luas areal maksimal 2 hektar untuk setiap kepala keluarga;

4. pada areal yang sedang berkonflik, diatur sesuai kondisi lapangan dan secara bertahap luas areal dibatasi 2 hektar; dan

5. batasan luas maksimal 2 hektar, tidak berlaku pada kerjasama pemungutan HHBK atau Jasling (BAB IV Pelaku Kemitraan Kehutanan Pasal 7, 10 dan $11)$.

Dasar hukum pelaksanaan pola kerjasama tersebut adalah Peraturan Menteri LHK HK P.81/Menlhk/Setjen/Kum.1/10/2016, yang bertujuan untuk menjamin pencapaian produksi pangan nasional, dengan menerapkan prinsip tata kelola hutan yang baik. Sedangkan jenis komoditas meliputi: tebu, padi, jagung, dan sapi. Adapun kawasan hutan yang digunakan untuk kegiatan tersebut meliputi areal izin pemanfaatan hutan, areal kerja Perum Perhutani, dan wilayah tertentu $\mathrm{KPH}$ yang berada pada hutan produksi. Luas areal untuk kegiatan tersebut maksimal 20.000 Ha dengan lama 10 tahun, dan yang paling penting adalah harus dapat memberikan kontribusi kepada negara sesuai ketentuan yang berlaku. Kerjasama Pemanfaatan Hutan di KPH 
Kerjasama pemanfaatan hutan di Kawasan Pengelola Hutan dilindungi oleh Peraturan Menteri LHK No. P.49/MenLHK/Setjen/Kum.1/9/2017. Adapun dasar dikeluarkannya peraturan menteri tersebut adalah pertimbangan untuk pelestarian hutan, sebagai pelaksanaan tugas dan fungsi $\mathrm{KPH}$, serta kemandirian KPH, serta sebagai bentuk kerjasama dengan pihak-pihak. Beberapa kegiatan yang bisa dilakukan dari kerjasama pemanfaatan di KPH anttara lain budidaya tanaman obat budidaya tanaman hias, jamur, budidaya lebah, budidaya ulat sutra, penangkaran satwa budidaya sarang burung walet; atau budidaya hijauan makanan ternak.

Kerjasama ini dapat dilakukan dengan pola agroforestry, silvopastura, dan/atau silvofishery. Bisa juga dilakukan kerjasama lingkungan, antara lain: pemanfaatan aliran air; pemanfaatan air; wisata alam; perlindungan keanekaragaman hayati; penyelamatan dan perlindungan lingkungan; penyerapan dan atau penyimpan karbon; atau pemanfaatan panas bumi (geothermal)

\section{Metode Penelitian}

Melalui penelitian suatu ilmu pengetahuan akan terperbaharui (up to date), terperbarukan, aplicated, dan dan aksiologis bagi penggunanya. Adapun pendekatan kualitatif adalah sebagai prosedur penelitian yang menghasilkan data deskriptif berupa kata-kata tertulisatau lisan dari orang-orang dan perilaku yang dapat diamati (Lexy J. Moleong. 2004 : 4). Metode penelitian yang digunakan dalam penelitian ini adalah penelitian kualitatif. Metode penelitian kualitatif digunakan dalam penelitian ini dengan tujuan untuk menggali bentuk - bentuk kemitraan pemerintah, swasta dan masyarakat dalam keberlanjutan program 
PLPBK di Kota Pekalongan dan Kabupaten Kendal. Metode pengumpulan data primer dilakukan dengan wawancara mendalam dengan informan yang dianggap dapat mewakili menjawab pertanyaan (key person) dan menggunakan teknik purposive sampling. Wawancara tersebut bertujuan untuk menggali bentuk-bentuk kemitraan pemerintah, swasta dan masyarakat. Pengumpulan data sekunder dilakukan apabila data yang didapatkan belum dapat dijadikan sebagai suatu informasi yang berkualitas dan diperlukan untuk mendukung fakta - fakta yang didapatkan dari wawancara yang dilakukan. Pengumpulan data sekunder yang dilakukan yaitu survei instansi dan kajian literatur. Berikut ini adalah tabel kebutuhan data yang diperlukan dalam penelitian beserta pengumpulan datanya

Penelitian kualitatif memiliki tahapan-tahapan, yaitu tahapan berpikir kritis ilmiah, maksudnya adalah seorang peneliti memulai berpikir kritis secara induktif yaitu menangkap berbagai fakta atau fenomena-fenomena sosial, melalaui pengamatan di lapangan, kemudian menganalisisnya dan lalu berupaya melakukan teorisasi berdasarkan pada apa yang diamati tersebut. menjadi jawaban sementara ilmiah (Burhan Bungin, 2009 : 6).

Berdasarkan penjelasan sebagaimana tersebut di atas, maka sangat proporsional apabila dalam penelitian ini menggunakan pendekatan kualitatif, mengingat permasalahan dalam penelitian ini adalah tentang perilaku manusia, tentang motivasi hidup suatu kelompok masyarakat, tentang interaksi timbal balik antara keberadaan hutan dengan lingkungan masyarakat sekitar hutan, dan tentang peningkatan kesejahteraan sebagai dampak dari keberadaan hutan. 
Denzin (dalam Moleong, 2005;330) menjelaskan ada empat macam triangulasi yang dapat dilakukan, yaitu triangulasi dengan sumber, triangulasi dengan metode, triangulasi dengan penyidik, dan triangulasi dengan teori. Melalui triangulasi ini akan dihilangkan perbedaan-perbedaan konstruksi kenyataan yang ada dalam konteks. Moleong $(2005 ; 332)$ berpendapat bahwa dengan triangulasi peneliti dapat me-recheck temuannya dengan jalan membandingkanya dengan berbagai sumber (pakar), metode, teori, atau data. Untuk itu maka peneliti dapat melakukannya dengan jalan

1. Mengajukan berbagai macam variasi pertanyaan;

2. Mengeceknya dengan berbagai sumber data; dan

3. Memanfaatkan berbagai metode agar pengecekan kepercayaan data dapat dilakukan.

\section{Kerangka Penelitian}

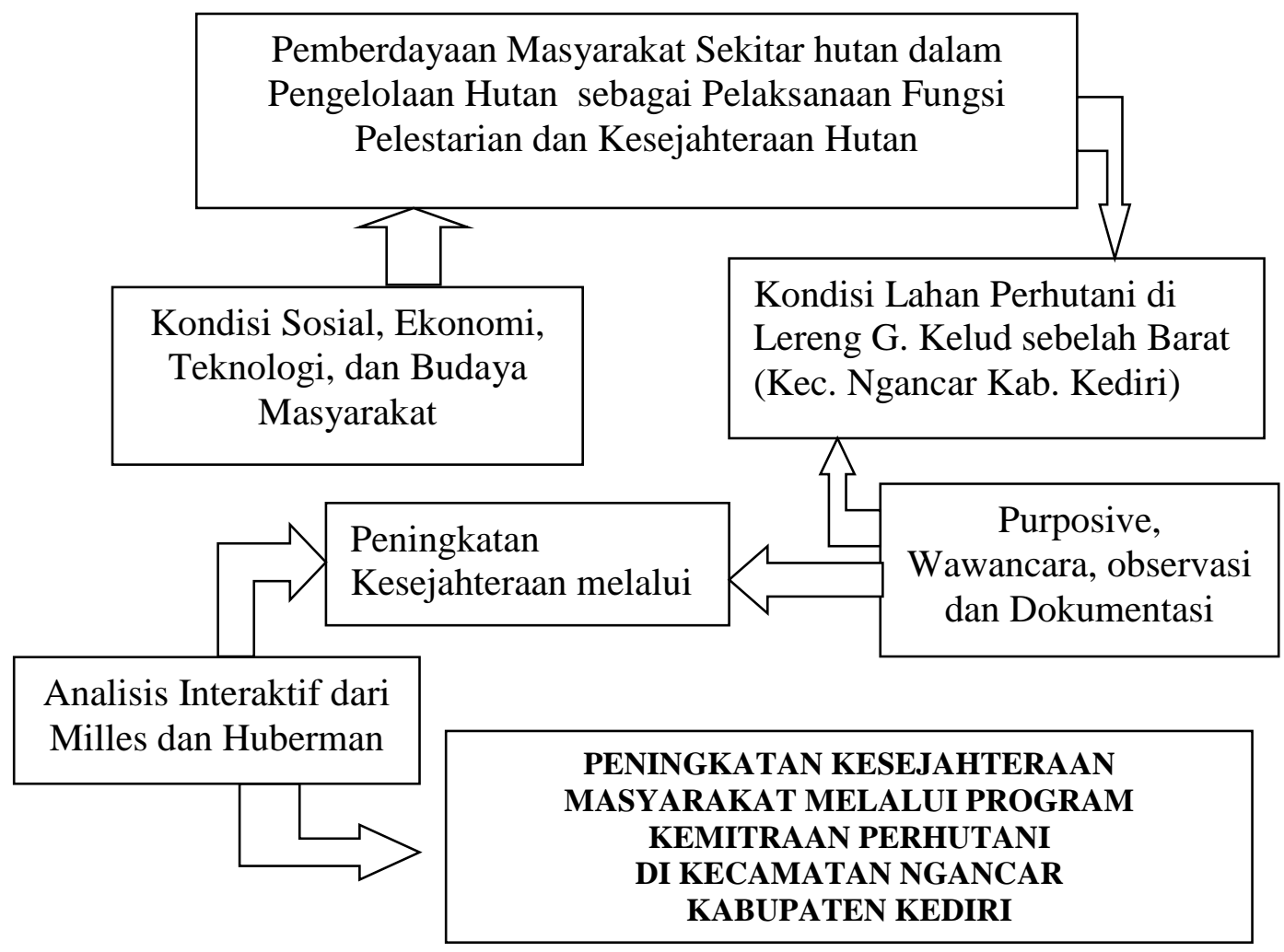




\section{Hasil Penelitian}

Keberadaan hutan lindung dan hutan produksi yang berdekatan dengan permukiman masyarakat selama ini selalu didera dengan adanya konflik. Konflik tersebut bisa berupa kerusakan lingkungan, pengrusakan hutan, pencurian hasil hutan, sampai pada terjadinya bencana alam. Melalui program kemitraan yang dilakukan oleh perhutani dengan memberdayakan masyarakat sekitar hutan dapat meminimalisir dan bahkan meniadakan konflik. disamping bnerbagai keuntungan lain yang dirasakan oleh masyarakat. Adapun keuntungan yang diperoleh oleh masyarakat sekitar hutan antara lain, masyarakat ikut menikmati keberadaan hutan, dengan cara menggarap sebagian lahan hutan denganm pembagian luas lahan yang telah ditentukan, demikian juga dengan jenis tanaman dan penggunaan pupuknya. Akibatnya masyarakat sekitar hutan bertambah lahan garapan, akibat lanjut adalah bertambah pula penghasilan sehingga meningkat pula kesejahteraannya. Masyarakat juga diijinkan mengelola lahan hutan tersebut untuk tujuan pengembangan wisata, baik itu wisata alam, wisata budaya, maupun wisata yang memanfaatkan tanaman atau kebun, misalnya kebun anggrek atau juga wisata sport (olahraga).

Disamping itu masyarakat ikut serta bertanggung jawab terhadap apa saja yang terjadi dengan kawasan hutan. Peningkatan kesejahteraanmasyarakat sekitar hutan melalui kerjasama dengan Perhutani dalam bentuk PHBM dan LMDH "Lancar Jaya". Akibat dari kerjasama tersebut petani memiliki lahan pertanian, pembagian lahan dilakukan secara random. Tanaman pertanian meliputi nanas,cabai, jagung, dan kacang panjang (tanaman sayuran). Peemasaran dibantu 
oleh LMDH "Lancar Jaya" , dalam pengelolaaan lahan tidak diperbolehkan menggunakan insektisida. Dengan demikian terjadi peningkatan penghasilan dan atau kesejahteraan masyarakat sekitar hutan. serta dapat meminimalisir kerusakan lingkungan dan konflik sosial.

Kendala yang dirasakan dalam melaksanakan program kemitraan dan pemberdayaan masyarakat sekitar hutan, antara lain Kendala internal meliputi kurangnya motivasi, dan saratnya pembatsan dalam pengelolaan lahan. Akibatnya hasil panen kurang optimal, mengingat tidak diperbolehkannya penggunaan insektisida serta tiadanya penyuluhan pertanian. Kendala Eksternal antara lain pengaruh iklim/cuaca dan wabah penyakit tanaman.

\section{Pembahasan}

Kementerian Lingkungan Hidup dan Kehutanan, Rabu, 6 September 2017. Membangun Indonesia dari pinggiran, didefinisikan oleh Kementerian Lingkungan Hidup dan Kehutanan (KLHK), salah satunya melalui program Perhutanan Sosial, sebuah program nasional yang bertujuan untuk melakukan pemerataan ekonomi dan mengurangi ketimpangan ekonomi melalui tiga pilar, yaitu: lahan, kesempatan usaha dan sumberdaya manusia. Perhutanan Sosial juga menjadi benda legal untuk masyarakat disekitar kawasan hutan untuk mengelola kawasan hutan negara seluas 12,7 juta hektar.

Akses legal pengelolaan kawasan hutan ini, dibuat dalam lima skema pengelolaan, yaitu Skema Hutan Desa (HD) hutan negara yang hak pengelolaannya diberikan kepada lembaga desa untuk kesejahteraan desa. Hutan Kemasyarakatan (HKm), yaitu hutan negara yang pemanfaatan utamanya 
ditujukan untuk memberdayakan masyarakat setempat. Hutan Tanaman Rakyat (HTR/IPHPS), adalah hutan tanaman pada hutan produksi yang dibangun oleh kelompok masyarakat untuk meningkatkan potensi dan kualitas hutan produksi dengan menerapkan silvikultur dalm rangka menjamin kelestarian sumber daya hutan. Hutan Adat (HA), dimana hutan ini adalah hutan yang berada di dalam wilayah masyarakat hutan adat. Skema terakhir adalah Kemitraan Kehutanan, dimana adanya kerjasama antara masyarakat setempat dengan pengelola hutan, pemegang Izin Usaha Pemanfaatan hutan, jasa hutan, izin pinjam pakai kawasan hutan atau pemegang izin usaha industri primer hasil hutan.

Pelaku Perhutanan Sosial adalah kesatuan masyarakat secara sosial yang terdiri dari warga Negara Republik Indonesia, yang tinggal di kawasan hutan, atau di dalam kawasan hutan negara, yang keabsahannya dibuktikan lewat Kartu Tanda Penduduk, dan memiliki komunitas sosial berupa riwayat penggarapan kawasan hutan dan tergantung pada hutan, dan aktivitasnya dapat berpengaruh terhadap ekosistem hutan. Perhutanan Sosial mulai di dengungkan sejak tahun 1999, keadaan Indonesia yang masih gamang pasca reformasi, menjadikan agenda besar ini kurang diperhatikan. Pada tahun 2007 program Perhutanan Sosial ini mulai dilaksanakan, namun selama lebih kurang tujuh tahun hingga tahun 2014, program ini berjalan tersendat. Kementerian Lingkungan Hidup dan Kehutanan mencatat selama periode 2007-2014, hutan yang terjangkau akses kelola masyarakat hanya seluas 449.104,23 Ha. Untuk itu setelah periode tersebut dilakukan percepatan-percepatan, dan selama kurang lebih tiga tahun masa 
Kabinet Kerja, telah tercatat seluas 604.373,26 Ha kawasan hutan, legal membuka akses untuk dikelola oleh masyarakat.

Dalam pelaksanaannya hingga saat ini, sejumlah 239.341 Kepala Keluarga (KK), telah memiliki akses legal untuk mengelola kawasan hutan nusantara, dan sejauh ini sosialisasi dan fasilitasi juga telah dilakukan kepada 2.460 kelompok, dimana fasilitasi yang diberikan adalah dalam bidang Pengembangan Usaha Perhutanan Sosial. Kementerian Lingkungan Hidup dan Kehutanan memiliki target untuk membentuk dan memfasilitasi lebih kurang 5000 Kelompok Usaha Perhutanan Sosial di Indonesia hingga tahun 2019.

Niatan menyejahterakan masyarakat Indonesia ini, bukan tidak memiliiki tantangan. Jauhnya masyarakat dari akses infrastruktur menjadi salah satu kendala terlaksananya verifikasi kelompok masyarakat, dan sering kali menjadi hal yang membuat terlambatnya sosialisasi program ini. Dalam pendampingan, Kementerian Lingkungan Hidup dan Kehutanan bekerjasama dengan multi pihak, termasuk LSM, dan program ini tentu saja membutuhkan banyak pendamping yang turun ke lapangan, yang memberikan pengetahuan dan pengidentifikasian potensi kawasan hutan, pengembangan usaha, serta pemasaran hasil usaha masyarakat, yang sering kita sebut sebagai akses ekonomi,hingga penguatan legal, sehingga masyarakat mampu mengadvokasi dirinya sendiri.

Akses legal mengelola kawasan hutan ini, diharapkan menjadi jembatan yang mampu memberikan bentuk nyata dari kehadiran negara dalam melindungi segenap bangsa Indonesia, dan memberi kesejahteraan bagi masyarkat daerah terdepan Indonesia. Perhutanan Sosial, ini saatnya hutan untuk rakyat. Ini juga 
menggambarkan implementasi dari Nawacita ke enam, yang ertujuan meningkatkan produktivitas masyarakat serta daya saing di tingkat internasional, sehingga bisa bersaing dengan negara-negara ditingkat ASEAN lainnya. Mewujudkan masyarakat yang mandiri secara ekonomi melalui sektor-sektor ekonomi strategis domestik, juga menjadi landasan dari program Perhutanan Sosial ini dilaksanakanMelalui program kemitraan perhutani tersebut masyarakat sekitar hutan, khususnya di sekitar lereng Gunung Kelud di Kecamatan Ngancar memperoleh tambahan penghasilan. Sebab melalui program kemitraan tersebut masyarakat sekitar memiliki lahan garapan (pertanian) yang hanya boleh ditanami tanaman jangka pendek. Hakekat dari program kemitraan tersebut adalah memberdayakan masyarakat sekitar hutan dalam pengelolaan hutan.

Pemberdayaan dimaksud adalah penggalian, pemanfaatan, potensi yang dimiliki oleh masyarakat sekitar hutan sesuai dengan keahlian atau ketrampilan yang dimiliki. Masyarakat yang memiliki potensi dan ketrampilan dibidang pertanian mereka memberdayakan aspek tersebut dibidang pertanian dengan cara memberi lahan garapan yang telah ditentukan, dan mereka mengerjakan lahan garapan tersebut untuk bidang pertanian (jangka Pendek). Oleh karena itu tanaman yang bisa ditanam antara lain tanaman terong, nanas, kacang panjang, ketimun dan lain sebagainya.Kemitraan tersebut tidak hanya terbatas pada pemberian lahan garapan saja sampai panen, namun juga sampai pada kemitraan dibidang pemasaran, bantuan pupuk dan menjual hasil panen.

Masyarakat yang memiliki keahlian atau ide/gagasan dibidang non pertanian, misalnya pariwisata, maka mereka juga mengembangkan lahan tersebut 
untuk kepentingan pariwisata, bisa berupa kebung anggrek, kampung Indian, Taman Agro, Kebun Strawberry, landasan offroad dan lain sebagainya. Sementara bagi pemerintah sebagai hasil atau akibat dari program kemitraan, antara lain Pelestarian lingkungan hutan menjadi lebih terjamin, pencurian kayu tidak terjadi, pemeliharaan tanaman hutan lebih bisa dihandalkan, tidak terjadi lagi konflik sosial yang disebabkan oleh keberadaan atau kerusakan hutan. Bagi masyarakat terjadi peningkatan kesejahteraan.

\section{Kesimpulan}

Telah terjadi peningkatan kesejahteraan masyarakat melalui program kemitraan Perhutani di Kecamatan Ngancar Kabupoaten Kediri. Hal tersebhut berdasarkan fakta bahwa lahan garapan pertanian masyarakat bertambah, sehingga dapat meningkatkan penghasilan, pemanfaatan lahan hutan untuk kepentingan wisata, baik itu wisata pertanian, wisata cultural, wisata sport, taman bunga, dan adanya kebun Anggrek maupun Kampung Indian. Program kemitraan yang dilaksanakan oleh Perhutani tersebut merupakan bentuk pemberdayaan masyarakat sekitar hutan.

\section{Saran}

7.1. Disarankan kepada pemerintah, khususnya Perhutani untuk terus dikembangkan program kemitraan dan pemberdayaan masyarakat.

7.2. Disarankan kepada Dinas Pariwisata, dan pertanian untuk terus mengembangkan kepariwisataan.

7.3. Bagi masyarakat sekitar hutan untuk terus mengembangkan dan memaksimalkan program pertanian, perkebunan dan kepariwisataan. 


\section{Daftar Pustaka}

Aprinasari, A. (2014). Pengembangan Kapasitas Kelembagaan Lokal dan Efektivitas Pelaksanaan Program Penataan Lingkungan Permukiman di Perkotaan. (Master), Universitas Diponegoro, Semarang.

Bungin, Burhan. 2009. Peelitian Kualitatif, Komuniikasi, Ekonomi, Kebijakan Publik dan Ilmu Sosial Lainnya. Jakarta Kencana. Jakarta.

Eko Edi Prastyo dan Kliwon Hidayat. 2016. Pola Kemitraan Antara Perum Perhutani Dengan Masyarakat Desa Hutan (Studi Kasus Program PKPH di Desa Kucur Dau, Kabupaten Malang). JURNAL HABITAT. ISSN: 0853-5167 (p); 2338-2007 (e), Volume 27, No. 3, Desember 2016, Hal. 139-149 DOI: 10.21776/ub.habitat.2016.027.3.16

Fatmawati, S. (2012). Peluang dan Tantangan Penanganan Lingkungan Permukiman Kumuh Berbasis Kawasan Melalui Kerjasama Komunitas-Swasta (Studi Kasus: Desa Kutoharjo, Kecamatan Kaliwungu, Kabupaten Kendal). (ST), Universitas Diponegoro, Semarang.

KangNur.com. 2018. https://www.kangnur.com/tiga-pola-kerjasamapemanfaatan-hutan-pada-kesatuan -pengelolaan-hutan.

Kuswanti. (2008). Gambaran Umum Kemitraan. Jakarta: Fakultas Kesehatan Masyarakat. Jakarta: Universitas Indonesia.

Lexy J. Moeleong. (2004). Metodologi Penelitian Kualitatif. Remaja Rosdakarya.Bandung:.

Miles, M. B., \& Huberman, A. M. (2009). Analisis Data Kualitatif. Jakarta: UI Press.

Putera, R. E. (2012). Analisis terhadap Program-program Penanggulangan Kemiskinan dan Pemberdayaan Masyarakat di Indonesia. Universitas Gadjah Mada, Yogyakarta

Peraturan Menteri LHK. 2017. No. P.49/MenLHK/Setjen/Kum.1/9/2017 tentang Kerjasama pemanfaatan hutan di Kawasan Pengelola Hutan. Jakarta.

Peraturan Menteri LHK HK P.81/Menlhk/Setjen/Kum.1/10/2016. Pemberdayaan Masyarakat Sekitar Hutan. Jakarta. 
Peraturan Menteri Kehutanan Republik Indonesia Nomor : P.39/Menhut-II/2013 tentang Pemberdayaan Masyarakat setempat melalui Kemitraan Kehutanan.

Peraturan Menteri Lingkungan Hidup dan Kehutanan. 2016. Nomor. P.83/MenLHK/Setjen/Kum.1/10/2016. Tentang kemitraan kehutanan. Jakarta. 